\title{
State of knowledge of the Corallinales (Rhodophyta) of Tierra del Fuego and the Antarctic Peninsula*
}

\author{
MARÍA LAURA MENDOZA \\ Centro Austral de Investigaciones Científicas, CADIC - CONICET, C.C. 92.9410 Ushuaia, Tierra del Fuego, Argentina.
}

\begin{abstract}
SUMMARY: Corallinales (Rhodophyta) in Tierra del Fuego are abundant, with 9 genera, 17 species and 1 subspecies. Pseudolithophyllum with 1 species (P. fueguianum), which represents $35.8 \%$ of the coralline algae, is dominant. The genera Parahydrolithon with 4 species $(P$. consociatum, $P$. discoideum, $P$. falklandicum, $P$. subantarcticum) and $20 \%$, Lithothamnion with 3 species (Lt. heterocladum, Lt. rugosum, Lt. granuliferum) and 17.5\%, and Synarthrophyton with 3 species (S. neglectum, S. patena, S. schmitzii) and 12\% share are abundant. Clathromorphum with 4 species (Cl. annulatum, Cl. lemoineanum, Cl. obtectulum, Cl. variabile) and a share of 5.8\%, and Mesophyllum with 1 species (M. fueguianum) and a share of $4.9 \%$ are frequent. The remaining three genera, Bossiella with 1 subspecies (B. orbigniana ssp. orbigniana), Corallina with 2 species (C. elongata, C. officinalis) (1.1\%), and Titanoderna with 1 species (T. conspectum) (1\%) are scarce. $C$. officinalis is a cosmopolitan, and the other geniculate corallines are found in both hemispheres, whereas the crustose coralline occur only in the southern hemisphere. The characteristic vertical distribution of the species in the intertidal and subtidal zone of Tierra del Fuego is given. The Corallinales in the Antarctic Region are poorly known and need further investigation.
\end{abstract}

Key words: Corallinales (Rhodophyta), Tierra del Fuego, Antarctic Peninsula.

RESUMEN: Estado de Conocimiento de las Corallinales (Rhodophyta) de Tierra del Fuego y Península AntáRTICA. - En Tierra del Fuego las Corallinales (Rhodophyta) son abundantes y están representadas por 9 géneros con 17 especies y 1 subespecie. Pseudolithophyllum con 1 única especie ( $P$. fueguianum) es dominante y representa el 35,8\% de las algas calcáreas. Parahydrolithon con 4 especies ( $P$. consociatum, P. discoideum, P. falklandicum, P. subantarcticum) (20\%), Lithothamnion con 3 especies (Lt. heterocladum, Lt. rugosum, Lt. granuliferum) (17,5\%) y Synarthrophyton con 3 especies (S. neglectum, S. patena, S. schmitzii) (12\%) son abundantes. Clathromorphum con 4 especies (Cl. annulatum, Cl. lemoineanum, $\mathrm{Cl}$. obtectulum, $\mathrm{Cl}$. variabile) $(5,8 \%)$ y Mesophyllum con 1 especie (M. fueguianum) $(4,9 \%)$ son frecuentes. Bossiella con 1 subespecie (B. orbigniana ssp. orbigniana), Corallina con 2 especies (C. elongata, C. officinalis) $(1 \%)$ y Titanoderna con 1 especie ( $T$. conspectum) $(1 \%)$ son escasas. C. officinalis es cosmopolita, las otras especies geniculadas crecen en ambos hemisferios, y las incrustantes son exclusivas del hemisferio austral. Se señala la distribución vertical de las especies en las zonas intermareal y submareal. Los trabajos de las Corallinales de la región Antártica son escasos, no pudiéndose precisar la biodiversidad de este grupo algal.

Palabras clave: Corallinales (Rhodophyta), Tierra del Fuego, Península Antártica.

\section{INTRODUCTION}

The coralline red algae (Rhodophyta, Corallinales) are one of the abundant seaweed groups in Tierra del Fuego, Argentina and represent a prin-

\footnotetext{
*Accepted October 5, 1998.
}

cipal component of the Fuegian marine ecosystems (Mendoza and Cabioch, 1986; Mendoza et al., 1996).

Coralline species have a restricted vertical distribution, and some are considered as indicators of distinct ecological zones in the intertidal and subtidal. Some species exhibit a marked and restricted geo- 
graphic distribution related to the water temperature. Some species occur exclusively in the Subantarctic regions.

\section{MATERIAL AND METHODS}

Data have been obtained from work carried out in Tierra del Fuego since the end of the last century by specialists in Corallinales: Foslie (1900, 1905, 1906, 1907), Heydrich (1900), Lemoine (1913, 1920); by phycologists: Ardissone (1888), Hariot (1895), Cotton (1915), Skottsberg (1923, 1941); and more recently by Mendoza (1976, 1988, 1990), Mendoza and Cabioch (1984, 1985, 1986, in press), Mendoza et al. (1996) and Cinelli et al. (1989).

Abundance percentage of genera is expressed by the sum of the species abundance of each genus. The abundance for each species was obtained either by counting of specimens or the cover of the encrusting thallus of the same species, which was then divided by the average thallus size. In both cases $25 \mathrm{~cm}$ squares were used, distributed every meter all along a transect perpendicular to the coast. The transects were done on low tide days during the summer months (November to March) in 1991, 1992, 1994 and 1995 along the Atlantic coast of Tierra del Fuego (Cabo San Pablo, Cabo Viamonte, Punta María, Caleta la Misión) and monthly in 1991, 1992, 1994 and 1995 along the Beagle Channel (Puerto Brown, Islas Bridges, Bahía Golondrina, Bahía Ensenada).

The delimitation of the intertidal and subtidal ecological levels is based on the corresponding indicator species for the coast of Tierra del Fuego. Occurrence of green algae communities (Enteromorpha prolifera, Enteromorpha intestinalis and Blidingia minima var. minima) delimits the upper intertidal zone; occurrence of the first plants of red algae (Notogenia fastigiata, Sarcothalia dichotoma, Bostrichia intricata), of encrusting coralline algae (Parahydroliton falklandicum, Synarthrophyton neglectum), and of brown algae (Corycus lanceolatus, Adenocystis utricularis) corresponds to the mid intertidal zone; and occurrence of the brown algae species Lessonia nigrescens to the lower intertidal zone. Lack of Lessonia nigrescens and occurrence of thalli of encrusting coralline Pseudolithophyllum fuegianum characterize the upper limit of the subtidal, and the occurrence of forests of brown algae Macrocystis pyrifera the lower subtidal zone.

\section{RESULTS AND CONCLUSIONS}

The studies of coralline algae are not very numerous in comparison with the other algae groups. The first work on coralline algae of Tierra del Fuego was carried out by Foslie (1900; 1905; 1906; 1907), Heydrich (1900) and Lemoine (1913; $1920)$, specialists in this algal group. Their identifications are based on the vegetative anatomy, especially the number of pores of the conceptacles. Other authors (Ardissone, 1888; Hariot, 1895; Cotton, 1915; Skottsberg, 1923, 1941) have reported other species. However, these studies were based on the external morphology only, and attempting to identify typical species of the boreal hemisphere in Tierra del Fuego.

In these first studies on the coralline algae of Tierra del Fuego 9 genera with 41 species were reported. Later Mendoza (1976, 1988, 1990), Mendoza and Cabioch (1984, 1985, 1986, in press) and Mendoza et al. (1996) studied the geniculate and crustose coralline algae of Tierra del Fuego. These authors, on the base of the reproductive and morphological characteristics of the species, gave an insight into the biodiversity of coralline algae. Their results are highly different from those presented in the early works (Table 1).

The geniculate coralline algae are not common and are only represented in two genera: Bossiella and Corallina, and the crustose coralline genera Lithophyllum, Epilithon, Melobesia, Neogoniolithon, and Phymatolithon do not occur along the Tierra del Fuego coast.

The recent studies by Mendoza et al. (1996) and Mendoza and Cabioch (in press), on the basis of type material and the new collections in the last few years in Tierra del Fuego, report 9 genera with 17 species and 1 subspecies: I. Bossiella with 1 subspecies [B. orbigniana ssp. orbigniana (Dcne.) Silva]; II Corallina with 2 species (C. elongata Ell. et Sol., C. officinalis L.); III. Clathromorphum with 4 species $[\mathrm{Cl}$. annulatum (Fosl.) Mendoza, $\mathrm{Cl}$. lemoineanum Mendoza et Cabioch, $\mathrm{Cl}$. obtectulum (Fosl.) Adey, Cl. variabile (Fosl.) Mendoza]; IV. Parahydrolithon with 4 species $[P$. consociatum (Fosl.) Mendoza et Cabioch, P. discoideum (Fosl.) Mendoza et Cabioch, P. falklandicum (Fosl.) Mendoza et Cabioch, P. subantarcticum (Fosl.) Mendoza et Cabioch]; V. Lithothamnion with 3 species ( $L$. granuliferum Fosl., L. heterocladum Fosl., L. rugosum Fosl.); VI. Mesophyllum with 1 species [M. fuegianum (Fosl.) Adey]; VII. Synarthrophyton with 3 
TABLE 1. - Former and present inventory of coralline algae in Tierra del Fuego. Species on the left were reported in prior studies, bold indicated species do not occur in Tierra del Fuego; species on the right are present identifications of those species that occur in Tierra del Fuego (Mendoza et al., 1996; Mendoza and Cabioch, in press).

\begin{tabular}{|c|c|c|}
\hline $\begin{array}{l}\text { I. } \\
1 \\
2 \\
\text { II. } \\
1 \\
\text { III. } \\
1 \\
2 \\
3 \\
4 \\
5 \\
\text { IV. } \\
1 \\
\text { V. } \\
1 \\
2 \\
3 \\
4 \\
5 \\
6 \\
7 \\
8 \\
9 \\
10 \\
11 \\
12 \\
\text { VI. } \\
1 \\
2 \\
3 \\
4 \\
5 \\
6 \\
7 \\
8 \\
9 \\
10 \\
11 \\
12 \\
13 \\
14 \\
15 \\
\text { VII. } \\
1 \\
\text { VIII. } \\
1 \\
\text { IX. } \\
1 \\
\end{array}$ & 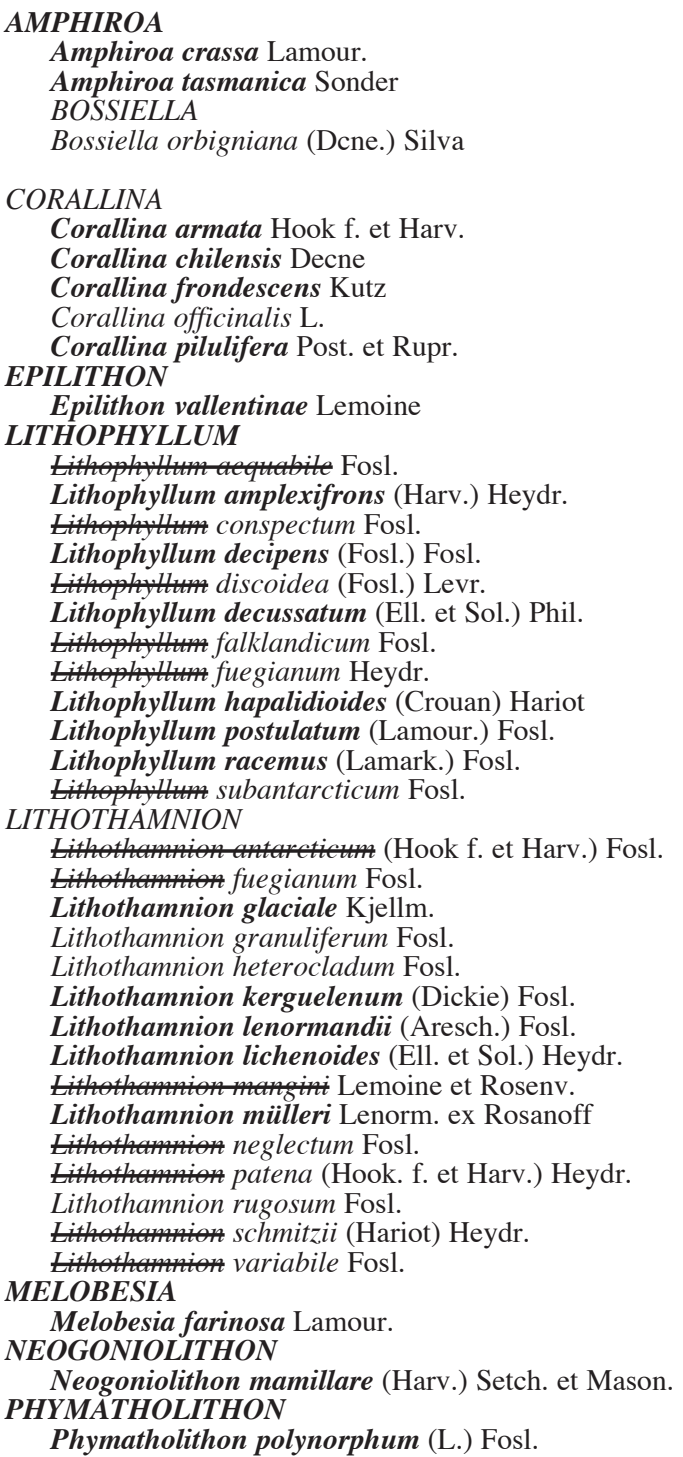 & $\begin{array}{l}\text { Clathromorphum obtectulum } \\
\text { Titanoderma conspectum } \\
\text { Parahydrolithon discoideum } \\
\text { Parahydrolithon falklandicum } \\
\text { Pseudolithophyllum fuegianum } \\
\text { Parahydrolithon subantarcticum } \\
\text { Synarthrophyton patena } \\
\text { Mesophyllum fuegianum } \\
\text { Lithothamnion granuliferum } \\
\text { Lithothamnion heterocladum }\end{array}$ \\
\hline
\end{tabular}

species [S. neglectum (Fosl.) Mendoza, S. patena (Hook. et Harv.) Townsend, S. schmitzii (Hariot) Mendoza], and the 2 restant genera with only 1 species VIII. Pseudolithophyllum [P. fuegianum (Heydr.) Mendoza et Cabioch]; and IX. Titanoderma [T. conspectum (Fosl.) Woelkerling].

Mendoza and Cabioch (1986, in press) and Mendoza et al. (1996) reported that the coralline algae in Tierra del Fuego often occur in a high number of specimens of the same species and do not show a great specific diversity. Moreover, the crustose coralline are more abundant than the geniculate group. The genus Pseudolithophyllum, with only one species, is dominant and represents $35.8 \%$ of the calcareous algae (Fig. 1). Three genera are abundant: Parahydrolithon, with 4 species (P. conspectum, $P$. discoideum, $P$. falklandicum, $P$. subantarcticum), making up 20\%; Lithothamnion, with 3 species, with $17.5 \%$; and Synarthrophyton, with 3 species, with $12 \%$. The genera Clathromorphum, with 4 species, with $5.8 \%$ share, and Mesophyllum, consisting of a single species $(4.9 \%)$, are frequent. Bossiella, with 1 subspecies, Corallina, with 2 species with $1.1 \%$, and Titanoderma, consisting of 1 species $(1 \%)$ are scarce (For names of species cf. last paragraph).

As to the vertical distribution, Mendoza and Cabioch (1986; in press), Mendoza et al. (1996) 


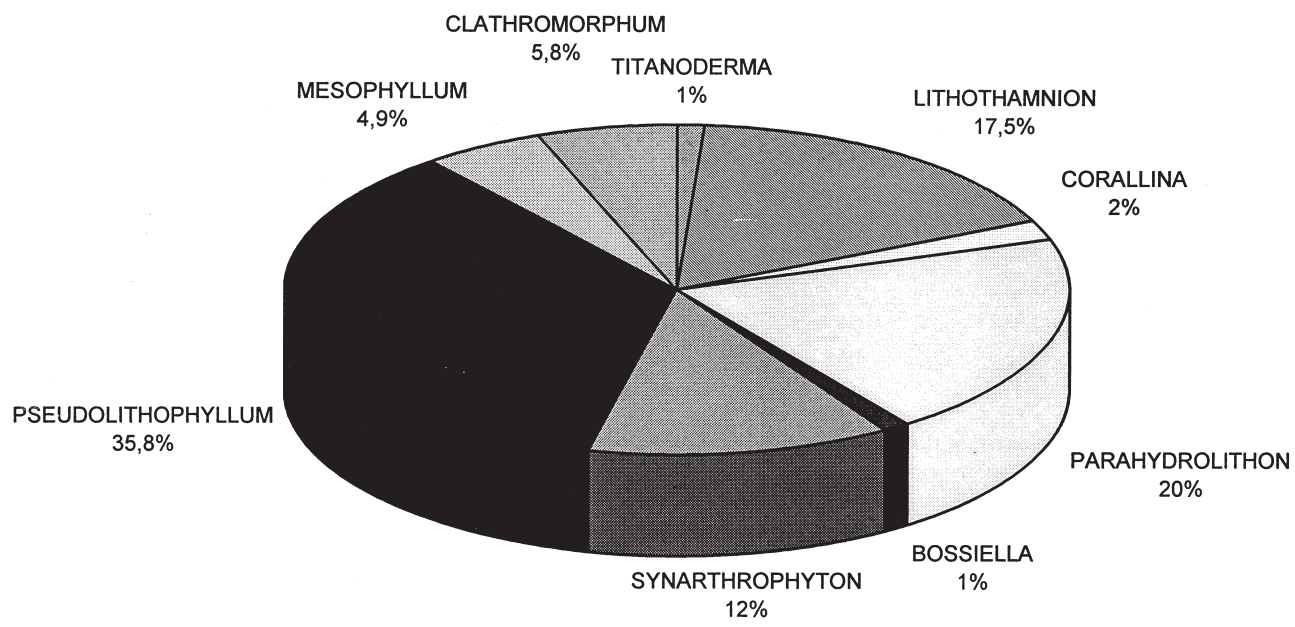

FIG. 1. - Diagrammatic representation of genera abundance of coralline algae in Tierra del Fuego, total material from various years included (see Materials and Methods) (Mendoza et al., 1993, in press; Mendoza and Cabioch, in press).

\section{INTERTIDAL SUBTIDAL}

\begin{tabular}{l}
\hline BOSSIELA \\
B. orbigniana (Dcne.) Silva \\
ssp. orbigniana \\
CORALLINA \\
C. elongata Ell. et Sol. \\
C. officinalis L. \\
\hline CLATHROMORPHUM \\
Cl. annulatum (Fosl.) Mendoza \\
Cl. lemoineanum Mendoza et Cabioch \\
Cl. obtectulum (FosI.) Adey \\
Cl. variabile (Fosl.) Mendoza \\
\hline PARAHYDROLITHON \\
P. consociatum (Fosl.) Mendoza \\
P. discoideum (FosI.) Mendoza et Cabioch \\
P. falklandicum (Fosl.) Mendoza \\
P. subantarcticum (Fosl.) Mendoza et Cabioch \\
\hline LITHOTHAMNION \\
Lt. granuliferum Fosl. \\
Lt. heterocladum Fosl. \\
Lt. rugosum Fosl. \\
MESOPHYLLUM \\
M. fuegianum (Fosl.) Adey \\
\hline SYNARTHROPHYTON \\
S. neglectum (FosI.) Mendoza \\
S. patena (Hook. et Harv.) Townsend \\
S. schmitzii (FosI.) Mendoza \\
PSEUDOLITHOPHYLUM \\
Ps. fuegianum (Heydr.) Mendoza et Cabioch \\
\hline TITANODERMA \\
T. conspectum (FosI.) Woelkerling \\
\hline
\end{tabular}

FIG. 2. - Vertical distribution of coralline algae in Tierra del Fuego, (Mendoza et al., 1993; 1996; Mendoza and Cabioch, in press) (see Materials and Methods). 
TABLE. 2. - Former and present inventory of coralline algae at the Antarctic Peninsula. Species on the left were reported in prior studies followed by the author who cited them in brackets, bold indicated species do not occur in the Antarctic Peninsula; species on the right are present identifications of those species (Mendoza et al. 1996; Mendoza and Cabioch, in press); ? shows problems in the taxonomic identification of the material which does not allow us to confirm the species (see Mendoza and Cabioch, 1984).

\begin{tabular}{llll}
\hline I LITHOPHYLLUM & & \\
1 & (Foslie) & Clathromorphum obtectulum \\
2 & Lithophyllum discoideum Fosl. & (Skottsberg) & ? \\
3 & Lithophyllum decipiens (Fosl.) Fosl. & (Skottsberg) & Parahydrolithon subantarcticum \\
4 & (Lemoine) & \\
II & LITHOTHAMNION & & Synarthrophyton patena \\
1 & Lithothamnion lenormandii (Aresch.) Fosl. & (Lemoine) & \\
2 & Lithothamnion lichenoides (Ell. et Sol.) Heydr. & (Skottsberg) & \\
3 & (Lemoine) & Parahydrolithon subantarcticum \\
5 & (Skottsberg) & Synarthrophyton schmitzii
\end{tabular}

reported the coralline algae present a marked and constant vertical distribution (Fig. 2). Synarthrophyton neglectum and Parahydrolithon falklandicum are the dominant species in the mid intertidal, $P$. falklandicum is exclusive in this zone and S. neglectum lives also down into the subtidal zone. Corallina elongata, $C$. officinalis, Clathromorphum annulatum, Cl. lemoineanum, $P$. discoideum, $P$. subantarcticum, Lt. grannuliferum, and Titanoderma conspectum occur from the lower intertidal downward. Bossiella orbigniana ssp. orbigniana, Clathromorphum lemoineanum, $\mathrm{Cl}$. variabile, Parahydrolithon consociatum, Lithothamnion heterocladum, $L t$. rugosum, Mesophyllum fuegianum, $S$. patena, S. schmitzii, Pseudolithophyllum fuegianun occur from the upper subtidal. In the lower subtidal zone the coalescent thalli of $P$. fuegianum cover the substrate, and L. heterocladum forms very long banks.

The crustose coralline algae are characteristic of the southern hemisphere (Mendoza and Cabioch, 1986; in press; Mendoza et al., 1996), the geniculate Corallina officinalis is a cosmopolitan, and C.elongata, Bossiella orbigniana ssp. orbigniana are found in both hemispheres.

The coralline algae are better known in the Antarctic region. The first studies were made by Foslie (1906) and Lemoine (1913), specialists in this algal group. Other species were reported by Skottsberg $(1923,1941)$, who was not a specialist in coralline algae. In these papers, 2 genera with 9 species were reported for this region. Lithophyllum is represented with 4 species (L. aequabile, L. discoideum, L. decipiens, L. subantarcticum), and Lithothamnion with 5 species (Lt. antarcticum, Lt. lenormandii, Lt. lichenoides, Lt. mangini, Lt. schmitzii). However, recent studies on the Corallinales of Tierra del Fuego (Mendoza et al., 1996;
Mendoza and Cabioch, in press) have allowed the taxonomic identity of the species cited for the Antarctic Peninsula to be corrected, except for Lithophyllum discoideum Foslie, which due to a wrong use as a synonym of L. fueguianum (see Mendoza and Cabioch, 1984) does not permit us to state whether it is Parahydrolithon discoideum (Foslie) Mendoza and Cabioch or Pseudolithophyllum fueguianum (Heydrich) Mendoza and Cabioch (Table 2).

Cinelli et al. (1989) carried out a short study of the coralline algae in the Antarctic region. In this paper, only 2 genera are given: Clathromorphum, with 2 species ( $\mathrm{Cl}$. obtectulum, $\mathrm{Cl}$. lemoineanum), and Parahydrolithon, with 1 species ( $P$. subantarcticum).

Consequently, since there is neither a detailed study, a review of the material already identified nor new, recently collected samples of coralline algae of the Antarctic Peninsula, it is not possible to specify at present the biodiversity of this algal group and compare it with that of Tierra del Fuego. However, we are aware of the abundance of coralline algae along the coasts of the Antarctic Peninsula, supported by the large amount of material collected in the First and Second "Expédition Antarctique Française" in 1903-1905 and 1908-1910, in the Herbario PC, Paris, which has unfortunately not been studied yet.

\section{REFERENCES}

Ardissone, F. - 1888. Le alghe della terra del Fuoco racolte dal Prof. Spegazzini. Rend. R. Ist. Lomb. Sci. Let., II 21 (4): 208215.

Cinelli, F., M.L. Mendoza and J. Cabioch. - 1989. Note sur quelques espèces des corallinacées (Rhodophyta) recoltés dans l'Antarctique. Phycologia, 28(1): 136-139.

Cotton, A.D. - 1915. Cryptogams from the Falkland Islands collected by Mrs. Vallentin. J. Linn. Soc. Bot., 43: 137-231.

Foslie, M. - 1900. Calcareous algae from Fuegia. In: O. Norden- 
skjöld: Wiss. Ergeb. Schwed. Exped. Magell. 1895-1897. Bot., 3, pp. 65-75. Stockholm.

Foslie, M. - 1905. Den botaniske samling. K. Norske Vidensk. Selk. Skr. Aarsb., 1904: 15-19.

Foslie, M. - 1906. Algologiske Notiser II. K. Norske Vidensk. Selsk. Skr., 2: 3-28.

Foslie, M. - 1907. Antarctic and subantartic Corallinaceae. In: Nordenskjöld, O.: Wiss. Ergeb. Schwed. Südp. Exped. 1901-1903. Bot., 4 (5), pp. 1-16. Stockholm.

Hariot, P. - 1895. Nouvelle contribution à l'étude des algues de la région magellanique. J. Bot., Paris, 9: 95-99.

Heydrich, F. - 1900. Les Lithothamniées de l'Expédition antarctique en Wildeman, E. de, Expédition antarctique belge. Note préliminaire sur les algues rapportées por M. E. Racovitza nat. de l'expéd. Bull. Class. Sci. Acad. Roy. Belgique, 1900, (7): 560-566.

Lemoine, Mme. P. - 1913. Mélobésiées. Révision de Mélobésiées antarctiques. In: J. Charcot: Deuxième Expéd. antarct. franc. 1908-1910, pp. 1-67. Edition Masson, Paris.

Lemoine, Mme. P. - 1920. Botanische Ergebnisse der schwedischen Expedition nach Patagonien und dem Feuerlande 1907-1909. VII. Les Mélobésiées. K. Sv. Vet. Akad. Handl., 61(4): 1-17.

Mendoza, M.L. - 1976. Estudio de las variaciones morfológicas externas, internas y citológicas de las Corallineae (Rhodophyta) de la Argentina. Physis, Secc. A, 35(90): 16-25.

Mendoza, M.L. - 1988. Estudio morfogenético, reproductivo, sistemático, y biogeográfico de algunos Lithothamnion (Corallinaceae) de las costas de la Isla Grande de Tierra del Fuego. Gayana, Bot., 45 (1-4): 173-191.

Mendoza, M.L. - 1990. Comportamiento ecológico de las Coralli- nales (Rhodophyta) en las costas del Canal Beagle, Argentina. Rev. Fac. Ocean., Pesq., Cs. Alimentarias, Perú, 2: 124-142.

Mendoza, M.L. and J. Cabioch. - 1984. Rédéfinition comparée de deux espèces de Corallinacées d'Argentine: Pseudolithophyllum fueguianum (Heydr.) comb. nov. et Hydrolithon discoideum (Fosl.) comb. nov. Cryptogamie, Algol., 4: 141-154.

Mendoza, M.L. and J. Cabioch. - 1985. Critique et comparaison morphogénétique des genres Clathromorphum et Antarcticophyllum (Rhodophyta, Corallinaceae). Conséquences biogéographiques et systematiques. Cah. Biol. Mar., 26: 251-266.

Mendoza, M.L. and J. Cabioch. - 1986. Les affinités biologiques et biogéographiques des Corallinacées (Rhodophyta) subantarctiques des côtes argentines et régions voisines. Bot. Mar., 29: 475-479.

Mendoza, M.L. and J. Cabioch. - in press. Parahydrolithon nov. gen., nouveau genre de Corallinales (Rhodophyta). Charactères morphologiques, reproducteurs et écologiques. Nova Hedwigia,

Mendoza, M.L., S. Molina and P. Ventura. - in press. Biogeografía de las Corallinales (Rhodophyta) de Tierra del Fuego. An. Ficol. III Congr. Latinoam. Is. Caribe, México.

Mendoza, M.L., S. Molina and P. Ventura. - 1996. Corallinales (Rhodophyta). Flora Criptogámica de Tierra del Fuego, 8(3): 1-71. Edition CONICET, Buenos Aires.

Skottsberg, G. - 1923. Botanische Ergebnisse der schwedischen Expedition nach Patagonien und dem Feuerlande 1907-1909. IX. Marine Algae 2. Rhodophyceae. Kgl. Svensk. Vet. Akad. Handl., 63 (8): 1-70.

Skottsberg, G. - 1941. Communities of marine algae in subantarctic and antarctic waters. Kgl. Svensk. Vet. Akad. Handl., III 19 (4): 1-92. 